\title{
SYNE2 Gene
}

National Cancer Institute

\section{Source}

National Cancer Institute. SYNE2 Gene. NCI Thesaurus. Code C120060.

This gene plays a role in organelle localization. 